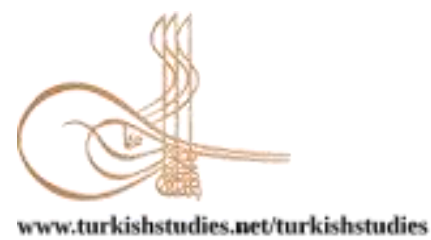

Turkish Studies

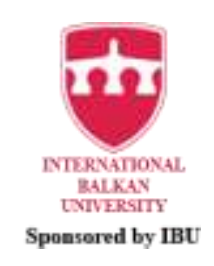

\title{
Üniversite Öğrencilerinin Yiyecek İçecek Seçimini Etkileyen Faktörlerin Analizi: Balıkesir Üniversitesi Örneği
}

\author{
Analysis of Factors Affecting Food and Beverage Choices of University Students: A Survey in the \\ Ballkesir University
}

\author{
Kudret Gül ${ }^{*}$ - Melike Gül**
}

\begin{abstract}
Since university students are extremely sensitive to change, their food preferences and the factors affecting these preferences differ significantly. The aim of the study is to determine the perception of factors affecting the food choices of university students based on demographic variables. The data were obtained from 503 students studying at 10 different faculties/colleges at the central campus of Balıesir University between January and February 2020. Participants were selected by simple random sampling technique among 30-70 students representing each faculty/college. Descriptive statistics, correlation and variance analysis were used in data analysis. The research findings show that the factors affecting students' food choices can be listed as physical conditions factors, psycho-social factors, factors related to food and drink, economic factors, psychological factors, demographic factors and cultural factors. Research results show that the perception of the factors affecting the food selection of the students differs based on gender and that female students are more sensitive than male students in choosing food. In addition, the education level of the mother also affects the perception of the students regarding food choices, and students whose mother's education level is low and high are more affected than those whose mother's education level is medium. Finally, university students' perception of food choice differs mostly based on faculty differences.
\end{abstract}

Structured Abstract: Healthy nutrition of university students is a very complex and multidimensional issue. In this context, the factors that affect the food and beverage choices of university students discussed in the study are also a multidimensional phenomenon. Current studies in the literature focus on the nutritional habits of university students, their knowledge about nutrition, the effect of economic and socio-cultural factors on nutrition. However, determining the factors affecting the food and beverage preferences of university students is very important for both the healthy nutrition of university students and the stakeholders who provide services especially for this target market. In this context, the aim of the study is to determine the perception of factors affecting the food choices of university students based on demographic variables.

\footnotetext{
* Doç. Dr., Balıkesir Üniversitesi, Balıkesir Meslek Yüksekokulu, Turizm ve Otel İşletmeciliği

Assoc. Prof. Dr., Balıkesir University, Balıkesir Vocational School, Tourism and Hotel Management

ORCID 0000-0002-9039-153X

kgul@balikesir.edu.tr

** Doç. Dr., Balıkesir Üniversitesi, Sındırgı Meslek Yüksekokulu, Turizm ve Otel İşletmeciliği

Ass0c. Prof. Dr., Balıkesir University, Sindırgı Vocational School, Tourism and Hotel Management

ORCID: 0000-0002-9046-4161

melikegul@balikesir.edu.tr

Cite as/ Atıf: Gül, K., \& Gül, M. (2021). Üniversite öğrencilerinin yiyecek içecek seçimini etkileyen faktörlerin analizi: Balıesir Üniversitesi örneği. Turkish Studies, 16(1), 473-492.
}

https://dx.doi.org/10.7827/TurkishStudies.47656

Received/Geliş: 17 November/Kasım 2020

Accepted/Kabul: 20 Şubat/February 2021 
Factors affecting the choice of food and beverage can be listed as demographic factors (age, gender, marital status, education and income status), genetic factors (physical appearance, weight and disease state), socio-cultural factors (family, friends, social status, religious beliefs), ecological and environmental factors, individual factors (hunger, satiety, mood, stress, habit, familiarity, preferences, sensory factors and personal motivation factors), food-related features (nutritional value, taste, sensory appeal, affordability, cost, quality, hygiene and ease of preparation), health factors, physical activity needs, social media and advertisements (Zunft et al., 1997; Neumark-Sztainer et al., 1999; Korkmaz, 2005; Bruening et al., 2012; Swanson et al., 2013; Girgin ve Karakaş, 2017; Vilaro et al., 2017; Voytyuk ve Hruschka, 2017; Gama et al., 2018; Keith et al., 2018; Gama et al., 2018; Sayg1, 2018; Zonneveld et al., 2019; González-Gil et al., 2019; Battaglia, 2020; Silventoinen ve Konttinen, 2020).

\section{Method}

The aim of the study is to determine the perception of the factors affecting the food and beverage choices of university students. The population of the study consists of Balikesir University students, and the research sample consists of 503 students studying at 10 different faculties / colleges in the central campus of the university. Participants were selected using the simple random sampling technique among 30-70 students representing each faculty. Questionnaire was used as a data collection tool in the study. Data were obtained between January and February 2020.

\section{Findings and Discussion}

Research findings based on factor analysis show that the factors affecting the food and beverage choice of the university students is physical conditions factor, psycho-social factor, food related factor, economic factor, psychological factor, demographic factor and cultural factor. On the other hand, correlation analysis reveals that physical conditions factor and psychological factors have a positive, statistically significant and strong relationship with the perception of factors affecting the food and beverage selection of students. The relationship between students' perception of food choice with cultural factors, food-related factors, economic factors and demographic factors is a moderate correlation. These findings show that university students are more affected by physical conditions and psychological factors in their food and beverage selection.

The perception of factors affecting food selection of the students differs based on gender. Cultural factors, psychological factors and food related factors are effective in this differentiation. Female students are more sensitive than male students in choosing food and drink. The education level of the mother also affects the students' perception of food and drink choices. This finding is similar to the findings of Şahin and Filiz (1999) that indicates education level of the mother is effective in the nutrition of the child. Father's education level has no effect on students' perception of food and drink choices.

In the study, it was revealed that the food choice perception of university students differs mostly based on the faculty differences. Tourism faculty students are the students most affected by the factors of food selection. In order of importance, medical and health faculty students follow tourism faculty students.

Economic factors affect students' perception of food and drink choices. In this perception, students who pay their tuition by working, scholarship and loan are more effective than students who pay their tuition with family support. Alcohol usage is also a reason that differentiates students' perception of food choices in terms of cultural factors and food related factors. The habit of skipping meals among students also affects the perception of food and drink choices. The findings reveal that students with the habit of skipping meals are more affected by economic and cultural factors than students who do not skip meals.

\section{Conclusion}

There are many studies in the literature on demographic, genetic, health, individual, socio-cultural, environmental, media and food feature factors that affect food choice. However, the study revealing the relationships between these factors and the effect of each factor on the individual's perception of food choice is quite insufficient. From this point of view, the aim of the study is to determine the factors affecting the food choice of university students, and the effect of each factors on the students' perception of food choice.

The food choice perception of university students is mostly affected by physical environment conditions and psychological factors. These factors are followed by cultural factors, factors related to food and beverage, economic factors and demographic factors according to their influence power. Based on these 
findings, it is recommended that stakeholders who provide food and beverage services to university students should focus on physical environmental conditions and psychological factors in the customer satisfaction.

Research results show that female students are more sensitive than male students in choosing food and drink. Cultural factors, psychological factors and factors related to food and drink are effective in this sensitivity. As the mother education level of the students decreases, the effect of economic factors on the choice of food and beverage increases. This result is in parallel with the findings in some studies in the literature (Yılmaz \& Özkan, 2007; Yıldırım et al., 2011; Onurlubaş et al., 2015) that economic difficulties are effective in student's nutrition.

Faculty differences is the most effective variable that affects the food selection perception of university students. Particularly, students of tourism faculties, medical faculties and health faculties, who are more aware of food and beverage, are more sensitive in choosing food and drink. This result coincides with the research results of James (2004) stating that individual food knowledge has an effect on eating habits. Alcohol usage and the habit of skipping meals also affect students' perception of food and drink choices. Economic, cultural and food related factors are more effective in these results. Research results may guide the shareholders in determining target market, customer satisfaction and developing new marketing approaches in the food and beverage market.

The study examines only university students' perceptions of the factors affecting food choices. In future studies, focusing on the customers' perception of the factors affecting their food choice may contribute more to the literature.

Keywords: Food Management, Food Selection, Perception of Food Selection Factors, University Student, Balıkesir University.

Öz: Değişime son derece duyarlı üniversite öğrencileri arasında yiyecek içecek tercihleri ve bu tercihleri etkileyen faktörler sürekli değişim göstermektedir. Bu kapsamda çalışmanın amacı, demografik değişkenlere dayalı üniversite öğrencilerinin yiyecek içecek seçimini etkileyen faktörler algısını belirlemektir. Veriler Ocak-Şubat 2020 ayları arasında Balıkesir Üniversitesi merkez yerleşkesinde 10 farklı fakülte/yüksekokulda öğrenim gören ve anket formunu doldurmayı kabul eden 503 öğrenciden elde edilmiştir. Katılımcılar, zümrelere göre örnekleme yöntemi ile her fakülte/yüksekokulu temsilen 30-70 öğrenci arasından basit tesadüfi örneklem tekniği ile seçilmiştir. Veri analizinde betimleyici istatistik, korelasyon ve varyans analizi kullanılmıştır. Araştırma bulguları, öğrencilerin yiyecek içecek seçimini etkileyen faktörlerin fiziki koşullar faktörleri, psiko-sosyal faktörler, yiyecek-içeceğe ilişkin faktörler, ekonomik faktörler, psikolojik faktörler, demografik faktörler ve kültürel faktörler olarak sıralanabileceğini ortaya koymaktadır. Öğrencilerin yiyecek içecek seçimini etkileyen faktörler algısının cinsiyete dayalı olarak farklılaştığı ve kız öğrencilerin yiyecek içecek seçiminde erkek öğrencilere kıyasla daha duyarlı oldukları tespit edilmiştir. Anne eğitim düzeyinin de öğrencilerin yiyecek içecek seçimi algısını etkilediği, anne eğitim düzeyi ilkokul ve üniversite/lisansüstü olan öğrencilerin, anne eğitim düzeyi lise olanlara kıyasla yiyecek içecek seçimini etkileyen faktörlerden daha fazla etkilendiği ortaya çıkmıştır. Ayrıca üniversite öğrencilerin yiyecek seçimi algısının en fazla fakülte/YO değişkenine dayalı olarak farklılaştığı ortaya çıkmıştır.

Anahtar Kelimeler: Yiyecek işletmeciliği, yiyecek seçimi, yiyecek seçim faktörleri algısı, üniversite öğrencisi, Balıkesir Üniversitesi.

\section{Giriş}

Beslenme, her canlı gibi insanlar için de en temel ihtiyaçlardan biridir. Beslenme ihtiyacı, insan hayatının her döneminde önemli olmakla beraber özellikle bebeklik, çocukluk ve gençlik döneminde daha da önemlidir. Ergenlik çağı ile olgunluk çağ1 arasında geçiş dönemi yaşayan üniversite öğrencileri açısından yeterli beslenme, bedensel büyüme ve gelişmenin yanında sağlıklı ruhsal gelişim için de bir gerekliliktir. Ancak yeterli ve dengeli beslenmenin taşıdığı bu öneme rağmen, ekonomik koşulların elverişsizliği, sosyo-kültürel faktörlerin etkisi, yaşam tarzı, anatomik veya psikolojik faktörlerin etkisi ile insanların karşılaştıkları beslenme sorunları tam olarak çözülememektedir. Özellikle beslenme hatalarına karşı bedenin daha hassas olduğu öğrencilik 
dönemlerinde, bir taraftan sağlıklı beslenme ile ilgili zorunluluklar artarken, diğer taraftan da hatalı beslenme alışkanlıklarına karşı alınan önlemler bireyin ileri yaşlarda karşılaşabileceği olası hastalıklardan korunabilmesi açısından da oldukça önemlidir.

Sağliklı ve dengeli beslenme oldukça karmaşık ve çok boyutlu bir konudur. Bu kapsamda çalışmada ele alınan, üniversite öğrencilerinin yiyecek-içecek seçimini etkileyen faktörler de çok boyutlu bir olgudur. Alan yazındaki konuya ilişskin çalışmaların üniversite öğrencilerinin beslenme alışkanlıkları, beslenmeye ilişkin bilgi düzeyleri, ekonomik ve sosyo-kültürel faktörlerin beslenme üzerindeki etkisi konularında odaklandığ görülmektedir. Ancak üniversite öğrencilerinin yiyecekiçecek tercihlerini etkileyen faktörlerinde belirlenmesi, özellikle bu hedef kitleye yönelik hizmet sunan yiyecek işletmeleri açısından oldukça önemlidir. Bu yaklaşımdan hareketle çalışmada, alan yazında genellikle birbirinden bağımsız olarak ele alınan öğrencilerin yiyecek-içecek tercihleri ve bu tercihleri etkileyen faktörlere ilişkin konuların bütüncül bir yaklaşımla ele alınması tercih edilmiştir. Bu yaklaşımdan hareketle çalışmanın amacı, Balıkesir Üniversite'sinde öğrenim gören öğrencilerin yiyecek içecek seçimini etkileyen faktöre ilişkin algılarını belirlemektir. Böylece araştırmada elde edilecek bulguların, öğrenciler, hizmet sunucuları, karar alıcılar ve diğer paydaşlar açısından yol gösterici olacağ̀ düşünülmektedir.

\section{Kuramsal Çerçeve}

Alan yazın incelendiğinde yiyecek içecek seçimini etkileyen faktörler yaş, cinsiyet, medeni hal, eğitim düzeyi ve gelir durumu gibi demografik faktörler (Zunft et al., 1997; Korkmaz, 2005; Ermiş vd., 2015; Gama et al., 2018; Sayg1, 2018); fiziki görünüş, kilo ve hastalık durumu gibi genetik faktörler (Ermiş vd., 2015; Silventoinen ve Konttinen, 2020); aile, arkadaşlar, sosyal statü, dini inançlar gibi sosyo-kültürel faktörler (Oygard ve Klepp, 1996; Neumark-Sztainer et al., 1999; James, 2004; Voytyuk ve Hruschka, 2017; Keith et al., 2018); ekolojik ve çevresel faktörler (Bruening et al., 2012; González-Gil et al., 2019; Battaglia, 2020); açlık, karın doyurma, ruh hali, stres, alışkanlık, aşinalık, tercihler, duyusal faktörler ve kişisel güdüleme faktörleri gibi bireysel faktörler (Neumark-Sztainer et al., 1999; Swanson et al., 2013; Girgin ve Karakaş, 2017; Keith et al., 2018; Gama et al., 2018; González-Gil et al., 2019); besin değeri, tat, duyusal çekicilik, fiyat uygunluğu, maliyet, kalite, hijyen ve hazırlama kolaylığı gibi gıdaya ilişkin özellikler (NeumarkSztainer et al., 1999; Korkmaz, 2005; Özdemir, 2010; Girgin ve Karakaş, 2017; Vilaro et al., 2017; Keith et al., 2018; Zonneveld et al., 2019); sağllk faktörü (Vilaro et al., 2017; Gama et al., 2018); fiziksel aktivite ihtiyacı (Neumark-Sztainer et al., 1999; Ermiş vd., 2015) ile sosyal medya ve reklamlar (Swanson et al., 2013; Vilaro et al., 2017) olarak siralanabilir.

Voytyuk ve Hruschka (2017: 126) bir insanın yeme standartlarının sosyo-kültürel yapıya bağl1 olarak günlük yaşamda içselleştirildiğini ve bu nedenle, rutinleşmiş ve kökleşmiş olduğu için yiyecek seçiminde oldukça etkili olduğunu ileri sürmektedirler. Battaglia (2020: 90) kuşaktan kuşağa genetik kod aktarımında ve mutasyonda çevre faktörlerinin oldukça etkili olduğunu ileri sürmektedir. Benzer bir yaklaşımla, Silventoinen ve Konttinen (2020: 150) genetik faktörlerin, genel beslenme ve iştah üzerinde açık bir etkisinin olduğunu vurgulamaktadırlar. Yapılan bir araştırmada ise kadınların erkeklere kıyasla sağlıklı beslenmeye daha fazla önem verdiği, yaş ilerledikçe hastalıklardan korunma beklentisinin arttığı, gençler arasında formda olma ve eğitim düzeyi yüksek olanlar arasında ise sağlıklı beslenme kaynaklı beklentilerin arttığı sonucuna ulaşı1mıştır (Zunft et al., 1997: 41).

Alan yazındaki üniversite öğrencilerinin beslenme alışkanlıkları ile ilgili yapılan bazı araştırmalar incelendiğinde ise bu öğrencilerin beslenme ile ilgili öğün atlama, tost ve simit gibi yiyeceklerle karın doyurmaya yönelik beslenme ve ekonomik güçlüklere bağlı yetersiz beslenme gibi çok ciddi sorunlar yaşadıkları ileri sürülmektedir (Orak vd., 2006; Yılmaz ve Özkan, 2007; Yıldırım vd., 2011; Onurlubaş vd., 2015; Ermiş vd., 2015). Oysa bir bireyin sağlıklı olarak gelişebilmesi ve yaşayabilmesi, ekonomik ve sosyal yönden gelişebilmesi ve refah düzeyinin artmasında temel koşullardan biri olup, gerekli olan besin öğelerinden her birini yeterli miktarda 
tüketimini ve sağlığa zararlı gıdalardan kaçınmayı zorunlu kılmaktadır (Ersin ve Beyhan, 2001; Tanır vd., 2001; Büyükpamukçu vd., 2003; Bozhüyük vd., 2012). Diğer taraftan beslenmenin fizyolojik olduğu kadar sosyolojik ve psikolojik yönleri de bulunmaktadır. Çalıştır vd. (2005) sorunun çözümü için dengeli beslenme, sağllklı olmayan besin tüketiminin önlenmesi, besin kaynaklarının daha ekonomik kullanımı ve bireylere yönelik beslenme eğitimi verilmesinin önemini vurgulamaktadırlar.

Işkıın ve Sarışsk (2017: 40) özellikle değişime son derece duyarlı üniversite öğrencileri arasındaki tüketim kalıplarının ve beslenme alışkanlıkların sürekli değiştiğini ileri sürmektedirler. Ancak bu süreçte sağlıklı beslenme, öğrencilerinin sağlıklı olarak yaşamlarını devam ettirebilmesi, okul başarısı ve ileriki yaşlarda oluşabilecek obesite, kalp damar hastalığı, diyabet, kanser gibi kronik hastalıkların önlenmesi açısından büyük önem taşımaktadır (Saygın vd., 2011: 44). Bu kronik hastalıklar genellikle erişkin dönemlerde ortaya çıkmakla birlikte, temelleri çocukluk ve gençlik yıllarındaki bilinçsiz beslenme alışkanlıklarına dayanır (Yıldırım vd., 2011:1377). Busch et al. (2010: 1104) üniversite öğrencilerine yönelik yaptıkları bir araştırmada öğrencilerin düzenli kahvaltı yapmamasının, fiziksel aktivite eksikliğinin, yüksek oranda alkol ve kahve tüketimi ile sigara kullanımının baş ağrısına neden olduğu sonucuna ulaşmışlardır. Yapılan bir başka araştırmada ise üniversite öğrencilerinin düzenli beslenmesi ile bilişsel performansı arasında pozitif ilişki olduğu saptanmıştır. Ayrıca başta tahıl bazlı ürünler olmak üzere yoğun mineral içeren besinlerin zihinsel performansı ve konsantrasyonu arttırdığı da rapor edilmektedir (Chung et al., 2012: 168-170). Ermiş vd. (2015) ise üniversite öğrencilerinin değişen beslenme alışkanlıklarının, onların zihinsel ve fiziksel durumunun yanında doğrudan veya dolaylı olarak okuldaki başarılarını da etkileyebildiğini ileri sürmektedirler. Mazıcıoğlu ve Öztürk (2003) ise üniversite öğrencilerinin bu geçiş sürecinde beslenme alışkanlıklarının düzenlenebilmesi ve uygunsuz beslenmenin yol açabileceği muhtemel bozuklukların önlenmesi için, karşılaştıkları uyum sorunlarının ve ekonomik sorunların kontrol altında tutulmasının gerekliliğine işaret etmektedirler.

González-Gil et al. (2019: 35) hem kız hem de erkek öğrencilerin sağlıklı beslenmesinde ailenin yanında bireysel ve çevre faktörlerinin de etkili olduğunu ileri sürmektedirler. Yapılan bir başka araştırmada ise öğrencilerin günlük yiyecek tüketiminde arkadaş grubunun ve en iyi arkadaşların etkili olduğu ortaya çıkmıştır (Bruening et al., 2012: 1608). Bir başka araştırmada ise öğrencilerin kaldığ 1 yerin beslenmeyi etkilediği, ekonomik durumun öğünlerin düzenli alımında etkili bir faktör olmadığı ve sigara içenlerin içmeyenlere kıyasla daha düşük oranda kahvaltı yaptığı sonucuna ulaşılmıştır (Mazıcıoğlu ve Öztürk, 2003:177). Diğer taraftan Gül'e (2013) göre de dünya genelinde kültürel, ekonomik, sosyal ve teknolojik değişimlerin etkisiyle insanların yeme alışkanlıkları son yıllarda etkileşim temelli olarak hızla yayılmaktadır. İnsanların ruhsal dönüşüm ve sosyalleşme ihtiyac1, eğlenme, statü ve değer kazanma gibi gereksinimleri de bu süreci hızlandırmaktadır. Korkmaz'ın (2005) yaptığı araştırmada müşterilerin demografik özelliklerin yanında ürünlerin temiz, sağlıklı ve kaliteli olmasının da müşteri tercihlerini etkilediği sonucuna ulaşılmıştır. James (2004:349) bireyin arkadaş çevresi ile akrabalarının, zaman kısıtının, bazı yiyeceklerin sosyal ve kültürel sembollerinin ve bilgi eksikliğinin sağliklı gida tüketimini engellediğini ileri sürmektedirler. Keith et al.. (2018:1017) bu engelleri tat, yiyecek hazırlama ve sağlıklı gıdayı belirlemede karşılaşılan güçlükler olarak sıralamaktadır. Oygard ve Klepp (1996) yaptıkları araştırmada gençler arasında yeme tarzını belirleyen en etkili sosyal faktörün ortak normlar olduğu ve insanların hayatları boyunca sosyalleşme araçlarının etkisi altında olduğu sonucuna ulaşmışlardır. Bir başka araştırmada ise ergenlerin yiyecek seçiminde en etkili parametrelerin kalite ve çabukluk olduğu ortaya çıkmıştır (Zonneveld et al., 2019: 240).

Neumark-Sztainer et al. (1999: 929) açlığın, yeme isteğinin, görünümün, zaman faktörünün, uygunluk ve elde edilebilirliğin, ailenin dini inançları ve kültürü gibi yeme alışkanlığını etkileyen faktörlerin, besin değeri, bireyin ruh hali, beden görünümü, alışkanlıklar, maliyet, medya ve vegeteryanlık faktörlerinin yiyecek-içecek seçimini etkilediğini ileri sürmektedirler. Girgin ve Karakaş (2017) ise yaptıkları bir araştırmada Türklerin yiyecek-içecek 
seçiminde en etkili olan faktörün duyusal faktör olduğu, bunu sırasıyla fiyat, uygunluk ve mevcudiyet, ruh hali, doğal gıda, sağlık, ekolojik, kilo, inanç ve aşinalık faktörlerinin izlediği sonucuna ulaşmışlardır. Vilaro et al. (2017:441) ise yüksekokul öğrencilerinin yiyecek seçimini etkileyen faktörler arasındaki öncelikleri belirlemeye yönelik yaptıkları araştırmada, bu faktörleri önem derecesine göre fiziksel görünüm, sağl1k, sosyal medya, kalite, fiyat, alışkanlıklar, sosyal statï, karın doyurma, stres, yakın arkadaşlar, tat, uygunluk, aile ve reklamlar olarak belirlenmişlerdir.

Yukarıdaki değerlendirmelerin 1şığında çalışmada, üniversite öğrencilerinin yiyecek seçimini etkileyen demografik, ekonomik ve sosyo-kültürel faktörlerden hangilerinin ne oranda bu tercihleri yönlendirdiği belirlenmeye çalışılmıştır. Böylece konu ile ilgili özellikle karar alıcılara ve diğer paydaşlara katkı sağlanması amaçlanmaktadır.

\section{Araştırmanın Amacı}

Çalışmanın amacı, Balıkesir Üniversite’sinde öğrenim gören öğrencilerin yiyecek içecek seçimini etkileyen faktöre ilişkin algısını ve bu algının demografik değişkenlere bağlı olarak farkl1lık gösterip göstermediğini ortaya çıkarmaktır.

\section{Yöntem}

Araştırmada nicel araştırma yöntemi ve veri toplama aracı olarak da anketten faydalanılmıştır. Veriler, Ocak-Şubat 2020 ayları arasında elde edilmiştir. Anket iki kısımdan oluşmaktadır. Birinci kısım katılımcıların demografik özelliklerini belirlemeye yönelik sorulardan oluşmaktadır. İkinci kısımda ise öğrencilerin yiyecek seçimini etkileyen faktörlerin belirlenmesine yönelik 28 maddelik beşli Likert ölçeği yer almaktadır. Bu soruların oluşturulmasında alan yazındaki konu ile ilgili (Korkmaz, 2005; Y1lmaz ve Özkan, 2007; Özdemir, 2010; Swanson et al., 2013; Girgin ve Karakaş, 2017; Işkın ve Sarışık, 2017; Saygı, 2018; Keith et al., 2018; GonzálezGil et al., 2019; Zonneveld et al., 2019) çalışmalarından yararlanılmıştır.

Araştırmada ilk olarak katılımcıların demografik özelliklerini belirlemek amacıyla betimleyici istatistiklerden yararlanılmıştır. İkinci olarak 28 maddelik ölçek güvenilirlik ve geçerlilik analizine tabi tutulmuştur. Son olarak da öğrencilerin yemek seçimini etkileyen faktörlere ilişkin algılarını belirlemeye yönelik varyans analizi uygulanmıştır. Çalışmada varyansların dağılımını belirlemek için yapılan Q-Q plot testi sonucunda, verilerin normal dağıldığ 1 ve varyans analizine uygun olduğu tespit edilmiştir. Değerlendirilen tüm veriler $\% 95$ güven aralığında incelenmiştir.

\section{Evren ve Örneklem}

Araştırmanın evrenini, Balıkesir Üniversitesi merkez kampüsünde çeşitli fakülte ve yüksekokullarda öğrenim gören üniversite öğrencileri oluşturmaktadır. Araştırmanın örneklemini ise Balıkesir Üniversitesi merkez kampüsünde 10 farklı fakülte/yüksekokulda öğrenim gören 503 öğrenci oluşturmaktadır. Katılımcılar, zümrelere göre (tabakalı) örnekleme yöntemi ile her fakülte ve yüksekokulu temsilen 30-70 öğrenci arasından basit tesadüfi örneklem tekniği ile seçilmeye çalışılmıştır. Ancak araştırmada karşılaşılan sınırlılıklar nedeniyle bazı fakültelerde hedeflenen örneklem büyüklüğüne ulaşılamamıştır. Yazıcıoğlu ve Erdoğan'a (2004) göre zümrelere göre örneklemede, ana kütle belirli özelliklere göre zümrelere ayrılmakta ve her zümreyi temsil edecek sayıda örnek ayrı ayrı basit tesadüfi örnekleme yolu ile çekilerek ana kütleyi temsil edecek örneğe ulaşılmaktadır.

\section{Güvenilirlik ve Geçerlilik Analizi}

Kalaycı'ya (2006: 405) göre, bir ölçeğin alfa katsayı değeri $0,40 \leq \alpha<0,60$ arasında ise ölçek düşük güvenilirliğe, ölçek değeri $0,60 \leq \alpha<0,80$ arasında ise ölçek orta düzey güvenilirliğe ve ölçek değeri $0,80 \leq \alpha<1,00$ arasında ise ölçek yüksek derecede güvenilirliğe sahiptir. Çalışmada 
öğrencilerin yiyecek içecek seçimini etkileyen faktörler (YISEF) algısı ölçeği bütününün ( $\Sigma \alpha=$ 0,836 ) yüksek derecede güvenilirliğe sahip olduğu ortaya çıkmıştır. Araştırmada kullanılan ölçek bütününün yapı geçerliliğini test etmek için ise faktör analizine başvurulmuştur. Bu amaçla, ölçeğin faktör analizine uygun olup olmadığını belirlemek için Kayser-Meyer-Olkin (KMO) değerine ve küresellik (Bartlett's Test) derecesine bakılmıştır. KMO değerinin 0,5'den büyük olması, kullanılan veri setinin faktör analizine uygun olduğunu göstermektedir (Kalayc1, 2006:327). Faktör analizi sonuçları, araştırmada kullanılan ölçek bütününe ilişkin KMO değerinin $(0,814)$ olduğu ve küresellik derecesinin de örneklem yeterliliğine sahip olduğunu göstermiştir $\left(X^{2}=4635,005\right.$; df:435; $\mathrm{p}<, 000)$. Bu sonuçlar, araştırmada kullanılan verilerden istatistiksel olarak anlamlı faktörler elde edilebileceğini işaret etmektedir. Bu yaklaşımdan hareketle, ikinci aşamada araştırma verileri temel bileşenler analizi ve Direct Oblimin döndürme yöntemi kullanılarak faktör analizine tabi tutulmuştur.

Tablo 1: Faktör Analizi Sonuçları

\begin{tabular}{|c|c|c|c|c|c|}
\hline \multicolumn{2}{|r|}{ Faktörler } & \multirow[t]{2}{*}{ Ort. } & \multirow[t]{2}{*}{ Yük } & \multirow{2}{*}{\begin{tabular}{|c|}
$\ddot{O ̈ z}$ \\
Değer \\
4,396 \\
\end{tabular}} & \multirow{2}{*}{$\begin{array}{c}\begin{array}{c}\text { Varyans } \\
(\%)\end{array} \\
19,115 \\
\end{array}$} \\
\hline No & I. Faktör ( 4 Madde) & & & & \\
\hline 18 & Mekânın fiziki yeterliliği yiyecek-içecek tercihlerimi etkilemektedir & 3,4791 & ,708 & & \\
\hline 19 & Mekânın fiziki görünümü yiyecek-içecek tercihlerimi etkilemektedir & 3,5487 & ,799 & & \\
\hline 20 & Havalandırma/sitma olanakları tercihlerimi etkilemektedir & 3,6521 & 758 & & \\
\hline \multirow[t]{2}{*}{21} & Müzik, internet ve yayınlar yiyecek-içecek tercihlerimi etkilemektedir & 3,1690 & ,706 & & \\
\hline & II. Faktör (3 Madde) & & & 2,774 & 12,061 \\
\hline 11 & Sosyalleşme amaçlarım yiyecek-içecek tercihlerimi etkilemektedir & 2,6044 & 783 & & \\
\hline 12 & Statü kazanma amaçlarım yiyecek-içecek tercihlerimi etkilemektedir & 2,2187 & ,861 & & \\
\hline \multirow[t]{2}{*}{13} & Moda ve gösteriş gibi irrasyonel faktörler tercihimi etkilemektedir & 1,9543 & 666 & & \\
\hline & III. Faktör ( 4 Madde) & & & 1,916 & 8,332 \\
\hline 24 & Hammadde kaynağının güvenli & 4,0358 & ,689 & & \\
\hline 25 & Yiyecek-içeceğin besin değeri tercihlerimi etkilemektedir & 3,4970 & 814 & & \\
\hline 27 & Sağlığım ve yiyecek-içeceklerin sağlıklılığı tercihlerimi etkilemektedir & 3,8410 & 677 & & \\
\hline \multirow[t]{2}{*}{30} & $\begin{array}{l}\text { Yiyecek-içeceğin beslenme alıskanlıklarıma uygunluğu tercihlerimi } \\
\text { etkilemektedir }\end{array}$ & 3,8250 & ,731 & & \\
\hline & IV. Faktör (4 Madde) & & & 1,747 & 7,596 \\
\hline 4 & Yiyecek-içecek tercihlerimde & 3,2883 & 750 & & \\
\hline 5 & bilmem önceliğimdir & 4,0994 & 657 & & \\
\hline 6 & Gelir durumum yiyecek-içecek tercihlerimi etkilemektedir & 3,8469 &, 716 & & \\
\hline \multirow[t]{2}{*}{7} & Rakip/diğer yiyecek-içeceklerin fiyatları tercihlerimi etkilemektedir & 3,4016 & 690 & & \\
\hline & V. Faktör (3 Madde) & & & $1, \mathbf{4 5 5}$ & 6,325 \\
\hline 14 & Mutluluk/eğlence arayışlarım tercihlerimi etkilemektedir & 3,2386 &,- 776 & & \\
\hline 15 & Günlük değişken ruh halim yiyece & 3,5984 &,- 781 & & \\
\hline \multirow[t]{2}{*}{16} & $\begin{array}{l}\text { Mekâna yönelik psikolojik yaklaşımım yiyecek-içecek tercihlerimi } \\
\text { etkilemektedir }\end{array}$ & 3,3598 &,- 737 & & \\
\hline & VI. Faktör (3 Madde) & & & 1,150 & 4,999 \\
\hline 1 & Cinsiyetimin yiyecek-içecek tercihlerimi etkilediğini düşünüyorum & 2,3320 &,- 710 & & \\
\hline 2 & Yaşımın yiyecek-içecek tercihlerimi etkilediğini düşünüyorum & 3,0040 &,- 829 & & \\
\hline \multirow[t]{2}{*}{3} & $\begin{array}{llll}\begin{array}{l}\text { Eğitim düzeyimin } \\
\text { düşünüyorum }\end{array} & \text { yiyecek-içecek tercihlerimi } & \text { etkilediğini } \\
\end{array}$ & 2,8151 &,- 565 & & \\
\hline & VII. Faktör (2 Madde) & & & 1,085 & 4,716 \\
\hline 9 & $\begin{array}{l}\text { Aile içi yetişme tarzım ve beslenme alışkanlıklarım tercihlerimi } \\
\text { etkilemektedir }\end{array}$ & 3,6759 &,- 750 & & \\
\hline \multirow[t]{2}{*}{10} & $\begin{array}{l}\text { Geldiğim bölgenin/yörenin mutfak kültürü yiyecek-içecek tercihlerimi } \\
\text { etkilemektedir }\end{array}$ & 3,6362 &,- 814 & & \\
\hline & TOPLAM & & & & 63,144 \\
\hline
\end{tabular}


Faktör analizinde, faktör yükü 0,5 'den daha düşük olan maddelerin ve birden fazla faktörde nitelik yükü 0,5 ve üstü olan sonuçların analiz dışı bırakılması gerektiği belirtilmektedir (Aydın vd., 2011: 92). Yapılan ilk faktör analizinde, faktör yükü 0,5 'in altında olan beş önermeye rastlanmış ve bu maddeler ölçek bütününden çıkartılarak, kalan 25 maddeye yeniden faktör analizi uygulanmıştır. Yapılan bu ikinci analiz sonucunda ise, iki maddenin rotasyon sonrası faktör yüklerinin belli bir faktörde toplanmadığı ve 0,5 'in altında değerler alarak yüklerin dağıldığı tespit edilmiştir. Bu nedenle söz konusu iki madde de ölçek bütününden çıkartılmıştır. Yapılan üçüncü faktör analizi sonucunda faktör yükü 0,5 ve özdeğeri 1'in üzerinde, toplam varyansin \% 63,144'ünü açıklayan, 23 maddeli 7 faktör elde edilmiştir (Tablo 1).

İlk faktör 4,396'lık özdeğer ve dört madde ile toplam varyansın \%19,1'ini açıklamaktadır. Bu faktörü oluşturan maddeler (18., 19., 20. ve 21. maddeler) katılımcıların fiziki koşulların yeterliliğine ilişkin algıları ile ilgili olup, faktöre fiziki koşullar faktörü (FKF) adı verilmiştir. İkinci faktör 2.774'lük özdeğer ve üç madde ile toplam varyansın \%12'ini açıklamaktadır. Bu faktörü oluşturan maddelerden ikisi (11. ve 12. maddeler) bireyin sosyal durumuna ilişkin algısı, bir madde ise (13. Madde) irrasyonel psikolojik algı ile ilgilidir. Bu faktöre de psiko-sosyal faktör (PSF) adı verilmiştir. Üçüncü faktör ise 1.916 'lık özdeğer ve dört madde ile toplam varyansın \%8,3'ünü açıklamaktadır. Bu faktörü oluşturan maddeler (24., 25., 27. ve 30. maddeler) katılımcıların yiyecek ve içeceklerin özelliklerine ilişkin algısı ile ilgili olduğundan, faktöre yiyecek-içeceğe ilişkin faktörler (YIF) adı verilmiştir. Dördüncü faktör 1,747 özdeğer ve dört madde ile toplam varyansın \%7,596'sını açıklamaktadır. Bu faktörü oluşturan maddeler (4., 5., 6. ve 7. maddeler) yiyecek seçiminde ekonomik faktörlerin etkisine ilişkin algı ile ilgilidir. Bu nedenle faktöre ekonomik faktörler (EF) adı verilmiştir. Beşinci faktör 1,455 özdeğer ve üç madde ile toplam varyansın \%6,325'ini açıklamaktadır. Bu faktörü oluşturan maddeler (14., 15. ve 16. maddeler) katılımcıların yiyecek içecek seçimine ilişkin psikolojik algıları ile ilgili olduğundan, faktöre psikolojik faktör (PF) adı verilmiştir. Altıncı faktör ise 1,15 özdeğer ve üç madde ile toplam varyansın \%4,999'unu açıklamaktadır. Bu faktörü oluşturan maddeler (1., 2. ve 3. maddeler), öğrencilerin demografik özelliklerinin yiyecek içecek seçimindeki etkisine ilişkin algıları ile ilgili olduğundan, faktöre demografik faktörler (DF) adı verilmiştir. Son olarak yedinci faktör 1,085 özdeğer ve iki madde ile toplam varyansın \%4,716'ını açıklamaktadır. Bu faktörü oluşturan maddeler (9. ve 10. maddeler), öğrencilerin yiyecek içecek seçiminde kültürel faktörlerin (KF) etkisine ilişkin algıları ile ilgilidir.

\section{Bulgular ve Tartışma}

Çalışmada katılımcıların demografik özelliklerini belirlemeye yönelik başvurulan frekans ve betimleyici analizlerin sonucu elde edilen bulgular Tablo 2'de görülmektedir.

Katılımcıların \%47,4'ü erkek, \%52,6'ı kız öğrencidir. Cinsiyet belirtmeyenlerin oranı ise $\% 1,4$ 'dür. Öğrencilerin \%53,0'ü yurtlarda, \%20,1'i aile yanında ve \%26,9'u ise arkadaşları ile evde kalmaktadırlar. Bulgular, öğrencilerin çoğunluğunun yurtlarda kaldığını göstermektedir. Öğrenci annelerinin $\% 36,7^{\prime}$ i ilkokul, $\% 26,5$ ' $i$ ortaokul, \%27,1'i lise ve sadece \%9,6's1 üniversite mezunudur. Babalarının ise \%20,2'si ilkokul, \%25,5'i ortaokul, \%34,1'i lise ve \%20,2'si üniversite mezunudur. Yapılan bir araştırmada anne eğitim düzeyinin çocuğun sağlıklı beslenmesinde etkili olduğu ve üniversite mezunu annelerin bu konuda daha bilinçli olduğu sonucuna ulaşılmıştır (Şahin ve Filiz, 1999:332). Araştırma bulguları, özellikle öğrenci anneleri arasında üniversite mezunu olanların oranının oldukça düşük olduğunu, buna karşın ilkokul mezunu olanların oranının ise yüksek olduğunu göstermektedir. Bu sonuçlar, ebeveyn eğitim düzeyi düşüklüğünün, üniversite öğrencilerinin yiyecek içecek seçimini etkileyen faktörler algısını etkileyebileceğini işaret etmektedir. 


\begin{tabular}{|c|c|c|c|c|c|c|c|c|c|}
\hline \multicolumn{10}{|c|}{ Tablo 2: Katılımcıların Demografik Özellikleri } \\
\hline Demografi & îk Özellikler & $\mathbf{N}$ & $\%$ & $\begin{array}{c}\% \\
\text { (Gecerli) }\end{array}$ & Demografi & k Özellikler & $\mathbf{N}$ & $\%$ & $\begin{array}{c}\% \\
\end{array}$ \\
\hline \multirow{4}{*}{ Cinsiyet } & Erkek & 235 & 46,7 & 47,4 & \multirow{4}{*}{ Kalınan Yer } & Yurt & 266 & - & 53,0 \\
\hline & Kadın & 261 & 51,9 & 52,6 & & Aile Yanı & 101 & - & 20,1 \\
\hline & Belirtmeyen & 7 & 1,4 & - & & Arkadaş/Ev & 135 & - & 26,9 \\
\hline & TOPLAM & 503 & 100,0 & 100,0 & & TOPLAM & 503 & - & 100,0 \\
\hline \multirow{6}{*}{ Anne Eğitim } & İlkokul & 184 & 36,6 & 36,7 & \multirow{6}{*}{$\begin{array}{c}\text { Baba } \\
\text { Ĕgitim }\end{array}$} & İlkokul & 101 & 20,1 & 20,2 \\
\hline & Ortaokul & 133 & 26,4 & 26,5 & & Ortaokul & 128 & 25,4 & 25,5 \\
\hline & Lise & 136 & 27,0 & 27,1 & & Lise & 171 & 34,0 & 34,1 \\
\hline & Ön/Lisans & 48 & 9,5 & 9,6 & & Ön/Lisans & 101 & 20,1 & 20,2 \\
\hline & Belirtmeyen & 2 & 0,4 & - & & Belirtmeyen & 2 & 0,4 & - \\
\hline & TOPLAM & 503 & - & 100,0 & & TOPLAM & 503 & - & 100,0 \\
\hline \multirow{9}{*}{ Fakülte/YO } & Mühendislik F. & 47 & - & 9,3 & \multirow{9}{*}{$\begin{array}{c}\text { Harçlı̆̆ı } \\
\text { Karşılama }\end{array}$} & Aile & 219 & - & 43,5 \\
\hline & Sağl1k Bil. F. & 20 & - & 4,0 & & Burs/Kredi & 61 & - & 12,1 \\
\hline & FEF & 70 & - & 13,9 & & Aile/Burs & 170 & - & 33,8 \\
\hline & N. Eğitim F. & 67 & - & 13,3 & & Çalışarak & 23 & - & 4,6 \\
\hline & Turizm F. & 65 & - & 12,9 & & Aile/Çalışarak & 13 & - & 2,6 \\
\hline & Tıp Fakültesi & 23 & - & 4,6 & & Burs/Çalışarak & 17 & - & 3,4 \\
\hline & BESYO & 65 & - & 12,9 & & TOPLAM & 503 & - & 100,0 \\
\hline & MYO & 68 & - & 13,5 & & & & & \\
\hline & TOPLAM & 503 & - & 100,0 & & & & & \\
\hline
\end{tabular}

Araştırmada harçlığını ailelerinden sağlayan öğrencilerin oranının \%43,5 olduğu ortaya çıkmıştır. Öğrencilerin \%33,8'i harçlığını hem aile hem de bursla karşılamaktadır. Aileden hiçbir destek almadan, sadece burs/kredi ile öğrenimine devam edenlerin oranı ise \%12,1'dir. Öğrencilerin \%4,6'sı ise ne aileden nede devletten hiçbir destek almadan çalışarak öğrenimlerini finanse etmektedir. Hem çalışarak hem de kısmen aile ve devlet desteği ile harcamalarını karşılayan öğrencilerin oranı ise \%6,0'dır. Buradaki son iki grup, çok ciddi sosyal bir sorunu işaret etmektedir. Nitekim, Başoğlu vd. (1992) ailelerin sosyo-ekonomik ve gelir düzeyleri ile gida harcamaları arasındaki ilişkiyi saptamak amacıyla yaptıkları bir çalışmada, ekonomik şartların, gıda tüketimini doğrudan etkilediği ve özellikle et, süt ve süt ürünleri gibi hayvansal yiyecekler için harcanan paranın, sosyo-ekonomik düzeyi düşük olan gruplarda, yüksek olan gruplara kıyasla oldukça az olduğunu ileri sürmektedirler. Bu görüş açısıyla bir değerlendirme yapıldığında, Balıkesir Üniversitesi öğrencilerinin ağırlıklı olarak sosyo-ekonomik açıdan hem gelir düzeyi hem de eğitim düzeyi düşük ailelerden geldiklerini, bu durumun öğrencilerin yiyecek içecek seçimini etkileyen faktörler algısını etkilediği ileri sürülebilir.

Araştırmada katılımcıların yiyecek seçimini etkileyen faktörler arası ilişkileri belirlemek amacıyla başvurulan korelasyon analizi sonuçları Tablo 3'de görülmektedir. 
Tablo 3: Değişkenlere İlişskin Korelasyonlar ve Tanımlayıcı İstatistikler

\begin{tabular}{|c|r|r|r|r|r|r|r|r|r|c|}
\hline Değişkenler & DF & EF & KF & PSF & PF & FKF & YIF & YISEF & Ort. & S.S \\
\hline DF & 1 & & & & & & & & 8,1511 & 3,22234 \\
\hline EF &, $096^{*}$ & 1 & & & & & & & 14,6362 & 3,43941 \\
\hline KF &, $268^{* *}$ &, $263^{* *}$ & 1 & & & & & & 7,3121 & 2,01290 \\
\hline PSF &, $299^{* *}$ &,$- 118^{* *}$ &, $179^{* *}$ & 1 & & & & & 6,7773 & 3,14239 \\
\hline PF &, $192^{* *}$ &, $169^{* *}$ &, $246^{* *}$ &, $234^{* *}$ & 1 & & & & 10,1968 & 2,87921 \\
\hline FKF &, $245^{* *}$ &, $209^{* *}$ &, $245^{* *}$ &, $109^{*}$ &, $420^{* *}$ & 1 & & & 13,8489 & 3,87312 \\
\hline YíF &, $093^{*}$ &, $183^{* *}$ &, $285^{* *}$ &,- 020 &, $149^{* *}$ &, $210^{* *}$ & 1 & & 15,1988 & 3,39912 \\
\hline YiSEF &, $483^{* *}$ &, $505^{* *}$ &, $572^{* *}$ &, $340^{* *}$ &, $603^{* *}$ &, $664^{* *}$ &, $556^{* *}$ & 1 & 101,7038 & 15,30467 \\
\hline
\end{tabular}

$\mathrm{N}=503$ için Korelasyon değerleri * 0,05 ve ** 0,01 düzeyinde anlamlıdır.

a. Demografik Faktörler (DF), b. Ekonomik Faktörler (EF), c. Kültürel Faktörler (KF), d. Psiko-sosyal Faktörler (PSF), e. Psikolojik Faktörler (PF), f. Fiziki Koşullar Faktörü (FKF), g. Yiyecek İçeceğe İlişkin Faktörler (YIF), h.Yiyecek İçecek Seçimini Etkileyen Faktörler Toplamı (YISEF)

Koreklasyon katsayıları incelendiğinde, demografik faktörler ile kültürel faktörler (r: 0,268**; p<0,01), demografik faktörler ile psiko-sosyal faktörler (r: 0,299**; p<0,01) ve demografik faktörler ile fiziki koşullar faktörü $\left(\mathrm{r}: 0,245^{* *} ; \mathrm{p}<0,01\right)$ arasında pozitif yönde ve istatistiksel olarak anlamll, ancak zayıf bir ilişki olduğu görülmektedir. Ekonomik faktörler ile kültürel faktörler (r: 0,263**; $\mathrm{p}<0,01$ ) ve ekonomik faktörler ile fiziki koşullar faktörü (r: 0,209**; $\mathrm{p}<0,01)$ arasındaki ilişki de zayıftır. Kültürel faktörlerin psikolojik faktörlerle (r: 0,246**; $<<0,01)$, fiziki koşullar faktörü (r: $0,245^{* *} ; \mathrm{p}<0,01$ ) ve yiyeceğe ilişkin faktörlerle olan ilişkisi de zayıf yönlüdür. Benzer biçimde zayıf bir ilişki psiko-sosyolojik faktörler ile psikolojik faktörler (r: $\left.0,234^{* *} ; \mathrm{p}<0,01\right)$ ve fiziki koşullar faktörü ile yiyeceğe ilişkin faktörler $\left(\mathrm{r}: 0,210^{* *} ; \mathrm{p}<0,01\right)$ arasında da söz konusudur. Psikolojik faktörler ile fiziki koşullar arasında ise ( $\left.r: 0,420^{* *} ; p<0,01\right)$ orta dereceli bir ilişki söz konusudur. Değişkenlerden fiziki koşullar faktörü (r: $0,664^{* *} ; \mathrm{p}<0,01$ ) ile psikolojik faktörlerin ( $\mathrm{r}: 0,603^{* *} ; \mathrm{p}<0,01$ ) öğrencilerin yiyecek içecek seçimini etkileyen faktörler algısı (YİSEF) ile olan ilişkisi ise pozitif yönde, istatistiksel olarak anlamlı ve güçlü bir ilişki olduğu ortaya çıkmıştır. Kültürel faktörlerin ( $\mathrm{r}: 0,572 * * ; \mathrm{p}<0,01$ ), yiyecek içeceğe ilişkin faktörlerin (r: $0,556^{* *} ; \mathrm{p}<0,01$ ), ekonomik faktörlerin (r: $0,505^{* *} ; \mathrm{p}<0,01$ ) ve demografik faktörlerin ( $\left(\mathrm{r}: 0,483^{* *} ; \mathrm{p}<0,01\right.$ ) yiyecek içecek seçimini etkileyen faktörler algısı ile olan ilişkisi ise orta dereceli bir korelasyon ilişkisidir. En düşük korelasyon ilişkisi ise psiko-sosyal faktörler değişkeni ile ölçek bütünü oluşturan yiyecek içecek seçimini etkileyen faktörler algısı arasında çıkmıştır (r: $\left.0,34^{* *} ; \mathrm{p}<0,01\right)$..

Çalışmada öğrenciler arasında demografik özelliklere dayalı yiyecek içecek seçimini etkileyen faktörler algısında farklılık olup olmadığını belirlemek için bağımsız örneklem t-test ve Anova analizine başvurulmuştur. Analiz sonuçları Tablo 4'de görülmektedir.

Katılımcıların cinsiyete dayalı yiyecek içecek seçimini etkileyen faktörler algısını belirlemek amacıyla başvurulan bağımsız örneklem t-test sonuçları, katılımcılar arasındaki algısı farklılığın ölçek bütünü açısından $(\mathrm{p}=0,010<0,05)$ istatistiksel olarak anlamlı olduğunu göstermektedir. Alt ölçeklerden kültürel faktörler $(\mathrm{p}=0,017<0,05)$, psikolojik faktörler $(\mathrm{p}=0,004<0,05)$ ile yiyecek içeceğe ilişkin faktörler $(\mathrm{p}=0,018<0,05)$ açısından da alg1 farklılığ istatistiksel olarak anlamlıdır. Ölçek bütününe yönelik bulgular, kız öğrencilerin yiyecek içecek seçiminde erkek öğrencilere kıyasla daha duyarlı olduklarını göstermektedir. Ortalamalar kız öğrencilerde 103,4943 ve erkek öğrencilerde ise 99,9702'dir. Alt ölçeklerden kültürel faktörlerin 
(kızlar 7,5249/erkekler 7,0936), psikolojik faktörlerin (k1z öğrenciler 10,5556/erkek öğrenciler 9,8213) ve gida özelliklerine ilişkin faktörlerin de (kız öğrenciler 15,5709/erkek öğrenciler $14,8511) \mathrm{kız}$ öğrencilerin yiyecek içecek seçimine etkisi erkek öğrencilere kıyasla daha fazladır. Katılımcılar arasinda cinsiyete dayalı demografik $(\mathrm{p}=0,337>0,05)$, ekonomik $(\mathrm{p}=0,657>0,05)$, psiko-sosyal $(\mathrm{p}=0,969>0,05)$ ve fiziki koşullar faktörlerinin $(\mathrm{p}=0,390>0,05)$ yiyecek içecek seçimi algısı üzerindeki etkisi ise istatistiksel olarak anlamlı değildir.

Üniversite öğrencilerinin anne ve baba eğitim düzeyinin yiyecek içecek seçimi algısı üzerindeki etkisini belirlemek amacıyla başvurulan Anova testi sonuçları, anne eğitim düzeyinin ölçek bütünü açısından katılımcıların yiyecek içecek seçimi algısı üzerindeki etkisinin istatistiksel olarak anlamlı olduğunu göstermektedir $(\mathrm{p}=0,046<0,05)$. Ortalamalar anne eğitim düzeyi ilkokul olanlarda 104,2120, üniversite ve lisansüstü mezunlarda 101,7844, ortaokul mezunlarında 100,5414 ve lise mezunlarında 99,7353'dür. Bu bulgular, anne eğitim düzeyi ilkokul olan öğrencilerin yiyecek içecek seçimini etkileyen faktörlerden daha fazla etkilendiğini, bu grubu anne eğitim düzeyi üniversite ve lisansüstü olan öğrencilerin izlemediğini ortaya koymaktadır. Anne eğitim düzeyi lise olanlar ise diğer gruplara kıyasla yiyecek içecek seçimini etkileyen faktörlerden en az etkilenen gruptur. Ölçek bütününü oluşturan alt ölçeklerden ekonomik faktörlerin $(\mathrm{p}=0,023<0,05)$ ve kültürel faktörlerin $(\mathrm{p}=0,020<0,05)$ de etkisi istatistiksel olarak anlamlıdır. Ortalamalar ekonomik faktörler için anne eğitim düzeyi ilkokul olanlarda 15.2554, ortaokul olanlarda 14.4436, lise olanlarda 14.2647 ve üniversite/lisansüstü mezunu olanlarda 14.0417 'dir. $\mathrm{Bu}$ sonuçlar öğrencilerin anne eğitim düzeyi düştükçe yiyecek içecek seçiminde ekonomik faktörlerden daha fazla etkilendiklerini göstermektedir. Kültürel faktörler için ise ortalamalar anne eğitim düzeyi ilkokul olanlarda 7.6467, ortaokul olanlarda 7.1429, lise olanlarda 7.0000 ve üniversite/lisansüstü olanlarda 7.5000'dır. Bu sonuçlar ise anne eğitim düzeyi ilkokul ve üniversite olan öğrencilerin yiyecek içecek seçimini etkileyen kültürel faktörlerden daha fazla etkilendiğini ortaya koymaktadır. Anne eğitim düzeyine ilişkin demografik faktörlerin, psiko-sosyal faktörlerin, psikolojik faktörlerin, fiziki koşullar faktörünün ve gıda özelliğine ilişkin faktörlerin etkisi de istatiksel olarak anlamlı değildir. Araştırmada baba eğitim düzeyinin de öğrencilerin yiyecek içecek seçimini etkileyen faktörler algısı üzerindeki etkisi istatiksel olarak anlamlı değildir $(\mathrm{p}=0,666>0,05)$.

Tablo 4: Demografik Özelliklere Dayalı Yiyecek-içecek Seçimini Etkileyen Faktörler Algısı

\begin{tabular}{|c|c|c|c|c|c|c|c|c|}
\hline \multicolumn{3}{|c|}{ Demografik Özellikler } & $\mathbf{N}$ & Yük & S.S. & df & $\mathbf{F}$ & $\mathbf{p}$ \\
\hline & \multirow[b]{2}{*}{ DF } & Erkek & 235 & 8,2979 & 3,22725 & \multirow[b]{2}{*}{494} & \multirow[t]{2}{*}{,015 } & \multirow[t]{2}{*}{,337 } \\
\hline & & Kadın & 261 & 8,0192 & 3,22902 & & & \\
\hline & \multirow{2}{*}{ EF } & Erkek & 235 & 14,5872 & 3,45976 & \multirow{2}{*}{494} & \multirow{2}{*}{,028 } & \multirow{2}{*}{,657 } \\
\hline & & Kadın & 261 & 14,7241 & 3,39917 & & & \\
\hline & \multirow{2}{*}{$\mathrm{KF}$} & Erkek & 235 & 7,0936 & 2,05682 & \multirow{2}{*}{494} & \multirow[t]{2}{*}{,262 } & \multirow[t]{2}{*}{,017 } \\
\hline & & Kadın & 261 & 7,5249 & 1,93260 & & & \\
\hline \multirow{9}{*}{ Cinsiyet * } & \multirow{2}{*}{ PSF } & Erkek & 235 & 6,7660 & 3,30509 & \multirow{2}{*}{494} & \multirow[t]{2}{*}{5,597} & \multirow[t]{2}{*}{ 969 } \\
\hline & & Kadın & 261 & 6,7548 & 3,01299 & & & \\
\hline & \multirow{2}{*}{$\mathrm{PF}$} & Erkek & 235 & 9,8213 & 2,89451 & \multirow{2}{*}{494} & \multirow[t]{2}{*}{,316 } & \multirow[t]{2}{*}{,004 } \\
\hline & & Kadın & 261 & 10,5556 & 2,82192 & & & \\
\hline & \multirow{2}{*}{ FKF } & Erkek & 235 & 13,7149 & 3,79940 & \multirow{2}{*}{494} & \multirow[t]{2}{*}{1,677} & \multirow[t]{2}{*}{ 390, } \\
\hline & & Kadın & 261 & 14,0153 & 3,95646 & & & \\
\hline & \multirow{2}{*}{ YİF } & Erkek & 235 & 14,8511 & 3,47013 & \multirow{2}{*}{494} & \multirow[t]{2}{*}{ 292 } & \multirow[t]{2}{*}{,018 } \\
\hline & & Kadın & 261 & 15,5709 & 3,22844 & & & \\
\hline & YİSEF & Erkek & 235 & 99,9702 & 15,24007 & 494 & 036 & ,010 \\
\hline
\end{tabular}




\begin{tabular}{|c|c|c|c|c|c|c|c|c|}
\hline & & Kadın & 261 & 103,4943 & 14,86338 & & & \\
\hline \multirow{17}{*}{ Anne Ĕ̈̆tim } & DF & Toplam & 501 & 8,1417 & 3,22519 & 3 & ,765 & ,514 \\
\hline & \multirow{4}{*}{$\mathrm{EF}$} & İlkokul & 184 & 15,2554 & 3,57969 & \multirow{4}{*}{3} & \multirow{4}{*}{3,221} & \multirow{4}{*}{, 023} \\
\hline & & Ortaokul & 133 & 14,4436 & 3,20136 & & & \\
\hline & & Lise & 136 & 14,2647 & 3,39768 & & & \\
\hline & & ÖnL./Lisans/L.Üst & 48 & 14,0417 & 3,11454 & & & \\
\hline & \multirow{4}{*}{$\mathrm{KF}$} & İlkokul & 184 & 7,6467 & 2,10910 & \multirow{4}{*}{3} & \multirow{4}{*}{3,290} & \multirow{4}{*}{, 020} \\
\hline & & Ortaokul & 133 & 7,1429 & 1,70179 & & & \\
\hline & & Lise & 136 & 7,0000 & 2,07275 & & & \\
\hline & & ÖnL./Lisans/L.Üst & 48 & 7,5000 & 2,07313 & & & \\
\hline & PSF & Toplam & 501 & 6,7725 & 3,13753 & 3 & ,933 & 425 \\
\hline & $\mathrm{PF}$ & Toplam & 501 & 10,2156 & 2,86800 & 3 & ,524 & ,666 \\
\hline & FKF & Toplam & 501 & 13,8643 & 3,87112 & 3 &, 539 & ,656 \\
\hline & YİF & Toplam & 501 & 15,2036 & 3,40506 & 3 & 531 & 661 \\
\hline & \multirow{4}{*}{ YİSEF } & İlkokul & 184 & 104,2120 & 16,87154 & \multirow{4}{*}{3} & \multirow{4}{*}{2,686} & \multirow{4}{*}{,046 } \\
\hline & & Ortaokul & 133 & 100,5414 & 14,08067 & & & \\
\hline & & Lise & 136 & 99,7353 & 13,76589 & & & \\
\hline & & ÖnL./Lisans/L.Üst & 48 & 101,7292 & 15,26188 & & & \\
\hline Baba Ĕ̈itim & YISEF & Toplam & 501 & 101,7844 & 15,27434 & 3 & 525 & ,666 \\
\hline \multirow{21}{*}{ Fakülte/YO } & \multirow{10}{*}{ DF } & Mühendislik & 47 & 9,6596 & 3,84638 & \multirow{10}{*}{9} & \multirow{10}{*}{3,763} & \multirow{10}{*}{, 000} \\
\hline & & Sağlık Bilimleri & 20 & 8,5500 & 3,39466 & & & \\
\hline & & Fen/Edebiyat & 70 & 8,1429 & 3,43168 & & & \\
\hline & & Eğitim & 67 & 7,8507 & 2,89332 & & & \\
\hline & & İkt./İdari Bilimler & 29 & 6,5517 & 3,26875 & & & \\
\hline & & Turizm & 65 & 8,9077 & 3,28216 & & & \\
\hline & & Beden Ĕgt/Spor & 65 & 8,0308 & 3,39563 & & & \\
\hline & & MYO & 68 & 7,9412 & 2,60242 & & & \\
\hline & & Veterinerlik & 49 & 6,8776 & 2,38601 & & & \\
\hline & & Tip & 23 & 9,1739 & 2,69093 & & & \\
\hline & \multirow{10}{*}{ EF } & Mühendislik & 47 & 15,1702 & 3,58935 & \multirow{10}{*}{9} & \multirow{10}{*}{3,520} & \multirow{10}{*}{, 000} \\
\hline & & Sağlık Bilimleri & 20 & 13,1000 & 4,12821 & & & \\
\hline & & Fen/Edebiyat & 70 & 14,8143 & 3,63674 & & & \\
\hline & & Eğitim & 67 & 15,0448 & 3,17868 & & & \\
\hline & & İkt./İdari Bilimler & 29 & 15,5862 & 3,20175 & & & \\
\hline & & Turizm & 65 & 15,9077 & 2,80470 & & & \\
\hline & & Beden Eğt/Spor & 65 & 13,3846 & 3,97921 & & & \\
\hline & & MYO & 68 & 14,6029 & 2,68850 & & & \\
\hline & & Veterinerlik & 49 & 13,8163 & 3,35207 & & & \\
\hline & & Tip & 23 & 13,7391 & 3,41411 & & & \\
\hline & $\mathrm{KF}$ & Mühendislik & 47 & 7,4255 & 1,96430 & 9 & 2,102 & ,028 \\
\hline
\end{tabular}




\begin{tabular}{|c|c|c|c|c|c|c|c|}
\hline & Sağlık Bilimleri & 20 & 8,0500 & 1,63755 & & & \\
\hline & Fen/Edebiyat & 70 & 7,3857 & 2,14201 & & & \\
\hline & Eğitim & 67 & 7,5075 & 1,90194 & & & \\
\hline & İkt./İdari Bilimler & 29 & 6,6897 & 2,30067 & & & \\
\hline & Turizm & 65 & 7,8769 & 2,12506 & & & \\
\hline & Beden E $\breve{g t} /$ Spor & 65 & 6,9385 & 1,97545 & & & \\
\hline & MYO & 68 & 6,9706 & 1,90028 & & & \\
\hline & Veterinerlik & 49 & 6,9184 & 1,81242 & & & \\
\hline & Tip & 23 & 7,7391 & 2,00493 & & & \\
\hline \multirow{10}{*}{ PSF } & Mühendislik & 47 & 8,1489 & 3,72990 & \multirow{10}{*}{9} & \multirow{10}{*}{4,015} & \multirow{10}{*}{,000 } \\
\hline & Sağlık Bilimleri & 20 & 7,2000 & 2,87640 & & & \\
\hline & Fen/Edebiyat & 70 & 6,5571 & 3,23314 & & & \\
\hline & Eğitim & 67 & 6,8358 & 3,09250 & & & \\
\hline & İkt./İdari Bilimler & 29 & 6,0000 & 3,12821 & & & \\
\hline & Turizm & 65 & 6,8000 & 2,90581 & & & \\
\hline & Beden Ĕ̆t/Spor & 65 & 8,0000 & 2,63391 & & & \\
\hline & MYO & 68 & 5,8088 & 3,06281 & & & \\
\hline & Veterinerlik & 49 & 5,6327 & 2,78907 & & & \\
\hline & Tip & 23 & 6,8696 & 3,07932 & & & \\
\hline \multirow{10}{*}{$\mathrm{PF}$} & Mühendislik & 47 & 10,5532 & 3,32846 & \multirow{10}{*}{9} & \multirow{10}{*}{2,164} & \multirow{10}{*}{, 023} \\
\hline & Sağlık Bilimleri & 20 & 11,0500 & 3,13679 & & & \\
\hline & Fen/Edebiyat & 70 & 10,2143 & 3,14801 & & & \\
\hline & Eğitim & 67 & 10,2687 & 2,77752 & & & \\
\hline & İkt./İdari Bilimler & 29 & 10,1724 & 2,84189 & & & \\
\hline & Turizm & 65 & 11,0923 & 2,29621 & & & \\
\hline & Beden Eğt/Spor & 65 & 9,8615 & 3,35818 & & & \\
\hline & MYO & 68 & 10,0000 & 2,24606 & & & \\
\hline & Veterinerlik & 49 & 8,9592 & 2,34485 & & & \\
\hline & Tip & 23 & 10,1304 & 3,20942 & & & \\
\hline FKF & Toplam & 503 & 13,8489 & 3,87312 & 9 & 1,146 & ,328 \\
\hline \multirow{10}{*}{ YİF } & Mühendislik & 47 & 14,0851 & 3,44415 & \multirow{10}{*}{9} & \multirow{10}{*}{2,768} & \multirow{10}{*}{,004 } \\
\hline & Sağlık Bilimleri & 20 & 15,4000 & 3,42437 & & & \\
\hline & Fen/Edebiyat & 70 & 15,7429 & 3,14705 & & & \\
\hline & Eğitim & 67 & 15,2836 & 3,38806 & & & \\
\hline & İkt./İdari Bilimler & 29 & 14,7586 & 4,05018 & & & \\
\hline & Turizm & 65 & 15,8462 & 2,59345 & & & \\
\hline & Beden Eğt/Spor & 65 & 14,4308 & 4,28649 & & & \\
\hline & MYO & 68 & 15,1765 & 3,10003 & & & \\
\hline & Veterinerlik & 49 & 14,6939 & 3,09707 & & & \\
\hline & Tip & 23 & 17,4348 & 2,53747 & & & \\
\hline
\end{tabular}




\begin{tabular}{|c|c|c|c|c|c|c|c|c|}
\hline & \multirow{10}{*}{ YİSEF } & Mühendislik & 47 & 103,4681 & 14,63298 & \multirow{10}{*}{9} & \multirow{10}{*}{3,732} & \multirow{10}{*}{,000 } \\
\hline & & Sağlık Bilimleri & 20 & 104,2500 & 15,70744 & & & \\
\hline & & Fen/Edebiyat & 70 & 103,4143 & 16,08266 & & & \\
\hline & & Eğitim & 67 & 102,7612 & 12,79452 & & & \\
\hline & & İkt./İdari Bilimler & 29 & 100,0000 & 16,76945 & & & \\
\hline & & Turizm & 65 & 107,9692 & 14,69478 & & & \\
\hline & & Beden Ĕgt/Spor & 65 & 96,7538 & 17,84047 & & & \\
\hline & & MYO & 68 & 100,1618 & 13,59171 & & & \\
\hline & & Veterinerlik & 49 & 94,8776 & 12,47937 & & & \\
\hline & & Tip & 23 & 105,1304 & 15,04631 & & & \\
\hline \multirow{8}{*}{$\begin{array}{c}\text { Harcamaları } \\
\text { Karşılama }\end{array}$} & \multirow{7}{*}{$\mathrm{EF}$} & Aile & 219 & 8,1050 & 3,06698 & \multirow{7}{*}{5} & \multirow{7}{*}{2,591} & \multirow{7}{*}{, 025} \\
\hline & & Burs/Kredi & 61 & 8,2131 & 3,18389 & & & \\
\hline & & Aile ve burs & 170 & 8,1353 & 3,36523 & & & \\
\hline & & Çalışarak & 23 & 8,5217 & 4,04373 & & & \\
\hline & & Aile ve çalışarak & 13 & 8,0769 & 3,12147 & & & \\
\hline & & Burs ve çalışarak & 17 & 8,2353 & 3,15296 & & & \\
\hline & & Toplam & 503 & 8,1511 & 3,22234 & & & \\
\hline & YİSEF & Toplam & 503 & 101,7038 & 15,30467 & 5 & 1,518 & ,185 \\
\hline \multirow{2}{*}{$\begin{array}{c}\text { Sigara } \\
\text { Kullanımi }\end{array}$} & \multirow{2}{*}{ YİSEF } & Evet & 200 & 101,1250 & 14,08586 & \multirow{2}{*}{497} & \multirow[b]{2}{*}{1,432} & \multirow{2}{*}{,446 } \\
\hline & & Hayır & 299 & 102,1538 & 15,69069 & & & \\
\hline \multirow{6}{*}{ Alkol Kullanımi* } & \multirow[b]{2}{*}{ KF } & Evet & 139 & 6,9496 & 1,96463 & \multirow[b]{2}{*}{469} & \multirow[b]{2}{*}{, 374} & \multirow[b]{2}{*}{, 010} \\
\hline & & Hayır & 332 & 7,4669 & 2,00048 & & & \\
\hline & \multirow{2}{*}{ YIF } & Evet & 139 & 14,6115 & 3,61661 & \multirow{2}{*}{469} & \multirow{2}{*}{3,245} & \multirow{2}{*}{,019 } \\
\hline & & Hayır & 332 & 15,4518 & 3,16467 & & & \\
\hline & \multirow[b]{2}{*}{ YISEF } & Evet & 139 & 100,6691 & 14,84382 & \multirow[b]{2}{*}{469} & \multirow[b]{2}{*}{, 067} & \multirow[b]{2}{*}{, 337} \\
\hline & & Hayır & 332 & 102,1 & 15,69069 & & & \\
\hline \multirow{6}{*}{ Öğ̈̈̈n Atlama* } & \multirow{2}{*}{$\mathrm{EF}$} & Evet & 73 & 13,5616 & 3,27018 & & & \\
\hline & & Hayır & 426 & 14,8099 & 3,44831 & 497 &, 539 & ,004 \\
\hline & & Evet & 73 & 6,8630 & 1,96012 & & & \\
\hline & KF & Hayır & 426 & 7,3756 & 2,01518 & 497 &, 171 &, 042 \\
\hline & & Evet & 73 & 98,3699 & 15,92561 & & & \\
\hline & YISEF & Hayır & 426 & 102,1808 & 15,09757 & 497 & ,982 & ,049 \\
\hline
\end{tabular}

* Bağımsız örneklem t-test uygulanmıştır.

Araştırmada üniversite öğrencilerin yiyecek seçimi algısı üzerinde en etkili olan değişkenin fakülte/YO değişkeni olduğu ortaya çıkmıştır. Fiziki koşullar alt ölçeği dışında $(p=0,328>0,05)$, ölçek bütünü YİSEF ( $p=0,000<0,05)$, demografik faktörler alt ölçeği $(p=0,000<0,05)$, ekonomik faktörler alt ölçeği $(p=0,000<0,05)$, kültürel faktörler alt ölçeği $(p=0,028<0,05)$, psiko-sosyal faktörler alt ölçeği $(p=0,000<0,05)$, psikolojik faktörler alt ölçeği $(p=0,023<0,05)$ ve yiyeceğe ilişkin faktörler alt ölçeği $(\mathrm{p}=0,004<0,05)$ açısından fakülte farklılı̆̆ına dayalı öğrenciler arasındaki yiyecek içecek seçimi algı farklılığ istatiksel olarak anlamlıdır. Ölçek bütünü YİSEF ortalamalarında, turizm fakültesi öğrencilerinin 107,9692 ile yiyecek içecek seçimini etkileyen faktörlerden en fazla etkilendikleri tespit edilmiştir. Bu öğrencileri 105,1304 ortalama ile tıp 
fakültesi öğrencileri, 104,2500 ortalama ile sağlık fakültesi öğrencileri, 103,4681 ortalama ile mühendislik fakültesi öğrencileri ve 103,4143 ortalama ile fen edebiyat fakültesi öğrencileri izlemektedir. Yiyecek içecek seçim faktörlerinden en az etkilenen öğrenciler ise 94,8776 ortalama ile veterinerlik fakültesi öğrencileri ve 96,7538 ortalama ile beden eğitimi ve spor fakültesi öğrencileridir. Yiyecek içecek seçiminde demografik faktörlerin en fazla etkisinde olan öğrenciler ise mühendislik fakültesi $(9,6596)$ ve tıp fakültesi $(9,1739)$ ögrencileridir. En az etkilenenler iktisadi ve idari bilimler fakültesi $(6,5517)$ ve veterinerlik fakültesi $(6,8776)$ öğrencileridir. Ekonomik faktörlerden en fazla etkilenen öğrenciler turizm fakültesi $(15,9077)$ ve iktisadi idari bilimler fakültesi $(15,5862)$ öğrencileridir. En az etkilenenler sağlık bilimleri fakültesi $(13,1000)$, beden eğitimi spor fakültesi $(13,3846)$ ve tıp fakültesi $(13,7391)$ öğrencileridir. Kültürel faktörlerin en çok sağlık bilimleri fakültesi $(8,0500)$, turizm fakültesi $(7,8769)$ ve tıp fakültesi $(7,7391)$ öğrencilerini etkilediği, buna karşın iktisadi idari bilimler fakültesi $(6,6897)$ ve veterinerlik fakültesi $(6,9184)$ öğrencilerinin ise daha az etkilendiği ortaya çıkmıştır. Yiyecek içecek seçimi algısında psiko-sosyal faktörlerden en fazla etkilenen öğrenciler mühendislik fakültesi $(8,1489)$, beden eğitimi spor fakültesi $(8,0000)$ ve sağlık bilimleri fakültesi $(7,2000)$ öğrencileridir. Veterinerlik fakültesi $(5,6327)$ ile MYO $(5,8088)$ öğrencileri ise en az etkilenen öğrencilerdir. Psikolojik faktörlerden en fazla etkilen turizm $(11,0923)$ ve sağlik bilimleri fakültesi $(11,0500)$ öğrencileridir. En az etkilenenler veterinerlik $(8,9592)$ ve beden eğitimi spor fakültesi $(9,8615)$ öğrencileridir. Tıp fakültesi öğrencileri 17,4348 ortalama ile yiyecek içeceğe ilişkin faktörler konusunda en hassas öğrencilerdir. Mühendislik $(14,0851)$ ve beden eğitimi spor fakültesi $(14,4308)$ öğrencileri ise gıdaya ilişkin özelliklere karşı en az duyarlı öğrencilerdir.

Araştırmada üniversite öğrencilerinin harcamalarını karşılama yolları dikkate alındığında ise öğrencilerin ölçek bütünü YİSEF açısından yiyecek içecek seçimini etkileyen faktörler algısının istatistiksel olarak anlamlı olmadığı sonucuna ulaşılmıştır $(\mathrm{p}=, 185>0,05)$. Yiyecek içecek seçimini etkileyen alt ölçeklerden sadece ekonomik faktörler öğrenciler arasında alg1 farklılığına neden olmaktadır $(\mathrm{p}=0,025<0,05)$. En yüksek ortalama çalışarak harçlı̆̆ını karşılayan öğrencilerdedir $(8,5217)$. Bu grubu harçlığını "burs ve çalışarak" karşılayanlar $(8,2353)$ ve "burs/kredi" ile karşılayanlar $(8,2131)$ izlemektedir. Bu bulgular, yiyecek içecek seçimi algısında ekonomik faktörlerin, harçlığını çalışarak, burs ve kredi ile karşılayan öğrencilerin, harçlığını aile desteği ile karşılayan öğrencilere kıyasla daha etkili olduğunu göstermektedir. Araştırmada alkol ve sigara kullanımının da ölçek bütünü YİSEF açısından öğrenciler arasında algı farklılığına neden olmadığı ortaya çıkmıştır (sigara için $\mathrm{p}=0,446>0,05$ ve alkol için $\mathrm{p}=0,337>0,05$ ). Ancak alkol kullanımı kültürel faktörler ve yiyeceğe ilişkin faktörler açısından öğrencilerin yiyecek içecek seçimi algısında farklılığa neden olmaktadır (KF için $p=0,010<0,05$ ve YIF için $p=0,019<0,05$ ). Ortalamalar kültürel faktörler için alkol kullanmayanlarda 7,4669 ve alkol kullananlarda 6,9496'dır. Yiyeceğe ilişkin faktörlerde ise ortalamalar alkol kullanmayanlarda 15,4518 ve alkol kullananlarda 14,6115'dir. Bu bulgular alkol kullanmayan üniversite öğrencilerinin yiyecek içecek seçimi algısında hem kültürel faktörlerin hem de yiyeceğe ilişkin faktörlerin daha etkili olduğunu göstermektedir. Diğer bir deyişle, alkol kullanmayan öğrenciler yiyeceklerin özelliklerini ve kültürel değerleri alkol kullanan öğrencilere kıyasla daha fazla dikkate almaktadırlar. Araştırmada öğrenciler arasında öğün atlama alışkanlığının da yiyecek içecek seçimi algısı üzerindeki etkisi belirlenmeye çalışılmıştır. Bulgular ögün atlama alışkanlığının ölçek bütünü YISSEF açısından $(\mathrm{p}=0,049<0,05)$, alt ölçeklerden ekonomik faktörler $(\mathrm{p}=0,004<0,05)$ ve kültürel faktörler $(\mathrm{p}=0,042<0,05)$ açısından öğrenciler arasında algı farklılığına neden olduğunu göstermektedir. Ortalamalar ölçek bütünü YİSEF'de öğün atlama alışkanlığı olan öğrencilerde 102,1808 ve öğün atlamayanlarda 98,3699'dur. Ekonomik faktörler açısından ise ortalamalar ögün atlayan öğrencilerde 14,8099 ve öğün atlamayanlarda 13,5616'dır. Kültürel faktörlerdeki ortalamalarda paralel biçimde öğün atlayan öğrencilerde 7,3756 ve öğün atlamayanlarda 6,8630'dur. Bu sonuçlar, öğün atlama alışkanlığı olan öğrencilerin ögün atlamayan öğrencilere kıyasla yiyecek içecek 
seçiminde ölçek bütünü YISEF, ölçek bütününü oluşturan alt ölçeklerden ekonomik faktörlerden ve kültürel faktörlerden daha fazla etkilendiğini ortaya koymaktadır.

\section{Sonuç ve Öneriler}

Alan yazın incelendiğinde yiyecek içecek seçimini etkileyen faktörler demografik faktörler, genetik faktörler, sosyo-kültürel faktörler, ekolojik ve çevresel faktörler, bireysel faktörler, gıdaya ilişkin özellikler, sağlık faktörü, fiziksel aktivite ihtiyacı ile sosyal medya ve reklamlar olarak sıralanabilir (Swanson et al., 2013; Ermiş vd., 2015; Vilaro et al., 2017; Sayg1, 2018; Keith et al., 2018; González-Gil et al., 2019; Zonneveld et al., 2019; Silventoinen ve Konttinen, 2020). Araştırmada başvurulan faktör analizi ise bu faktörlerin fiziki koşullar faktörü, psiko-sosyal faktörler, yiyecek-içeceğe ilişkin faktörler, ekonomik faktörler, psikolojik faktörler, demografik faktörler ve kültürel faktörler olarak sıralandığını ortaya koymaktadır. Araştırmada ayrıca başvurulan korelasyon analizi sonuçları ise bu faktörlerden fiziki koşullar faktörü ile psikolojik faktörlerin, öğrencilerin yiyecek içecek seçimini etkileyen faktörler algisı ile pozitif yönde, istatistiksel olarak anlamlı ve güçlü bir ilişkisi olduğunu göstermektedir. Bu bulgulardan hareketle, üniversite öğrencilerine yönelik yiyecek içecek hizmeti veren işletmelere fiziki ortamın çekiciliğini arttırıcı yenilikçi yöntemler geliştirmeleri önerilebilir. Benzer biçimde bu işletmelerdeki ortamın psikolojik olarak da gençleri cezbedici olmasında fayda bulunmaktadır. Kültürel faktörlerin, yiyecek içeceğe ilişkin faktörlerin, ekonomik faktörlerin ve demografik faktörlerin yiyecek içecek seçimini etkileyen faktörler algısı ile olan ilişkisi ise orta dereceli bir korelasyon ilişkisidir. $\mathrm{Bu}$ sonuçlar üniversite öğrencilerinin yiyecek içecek seçiminde daha çok ortama ilişkin fiziki koşullardan ve psikolojik faktörlerden etkilendiğini ortaya koymaktadır. Bu bulgunun, özellikle üniversite öğrencilerini hedef kitle olarak belirleyen yiyecek içecek işletmesi yöneticileri tarafından dikkate alınması önerilebilir.

Araştırmada yiyecek içecek seçimini etkileyen faktörler algısının cinsiyete dayalı olarak farklılaştı̆̆ 1 , bu farklılaşmada kültürel faktörlerin, psikolojik faktörler ile yiyecek içeceğe ilişkin faktörlerin etkili olduğu ve kı öğrencilerin yiyecek içecek seçiminde erkek öğrencilere kıyasla daha duyarlı oldukları ortaya çıkmıştır. Bu bulgular Zunft et al. (1997) çalışmalarındaki kadınların erkeklere kıyasla sağlıklı beslenmeye daha fazla önem verdiği yönündeki araştırma bulguları ile örtüşmektedir. Bu nedenle paydaşlara, öğrencilerin müşteri memnuniyetini arttırmada özellikle kız öğrencilere odaklanmaları önerilebilir.

Araştırmada anne eğitim düzeyinin de öğrencilerin yiyecek içecek seçimi algısını etkilediği sonucuna ulaşılmıştır. Bu bulgu, Şahin ve Filiz'in (1999) çalışmalarında ulaştıkları anne eğitim düzeyinin çocuğun beslenmesinde etkili olduğu yönündeki araştırma bulguları ile benzerlik göstermektedir. Araştırma sonuçları, anne eğitim düzeyi ilkokul ve üniversite/lisansüstü olan öğrencilerin, anne eğitim düzeyi lise olanlara kıyasla yiyecek içecek seçimini etkileyen faktörlerden daha fazla etkilendiğini göstermektedir. Bu etkide ekonomik ve kültürel faktörler belirleyici olmaktadır. Öğrencilerin anne eğitim düzeyi düştükçe yiyecek içecek seçiminde ekonomik faktörlerin etkisi daha da artmaktadır. Bu bulgu alan yazındaki bazı çalışmalarda ulaşılan (Yılmaz ve Özkan, 2007; Yıldırım vd., 2011; Onurlubaş vd., 2015) öğrencilerin beslenmesinde ekonomik güçlüklerin etkili olduğu yönündeki bulgular ile paralellik göstermektedir. Ayrıca anne eğitim düzeyi ilkokul ve üniversite olan öğrencilerin yiyecek içecek seçimi algısı kültürel faktörlerden daha fazla etkilenmektedir. Bu sonuçlardan hareketle, sağlıklı nesiller yetiştirmeye yönelik makro ölçekli politikalarda özellikle annelerin sağlıklı beslenme konusunda bilinçlendirilmesine odaklanılması yararlı olacaktır. Baba eğitim düzeyi ise öğrencilerin yiyecek içecek seçimi algısı üzerinde etkisi bulunmamaktadır.

Araştırmada üniversite öğrencilerin yiyecek seçimi algısının en fazla fakülte/YO farklıı̆̆ğı dayalı olarak farklılaştığı ortaya çıkmıştır. Yiyecek içecek seçimini etkileyen faktörlerden en fazla etkilenen öğrenciler turizm fakültesi öğrencileridir. Bu öğrencileri önem sırasına göre tıp fakültesi öğrencileri, sağlık fakültesi öğrencileri, mühendislik fakültesi öğrencileri 
ve fen edebiyat fakültesi öğrencileri izlemektedir. Yiyecek içecek seçim faktörlerinden en az etkilenen öğrenciler ise veterinerlik fakültesi öğrencileri ile beden eğitimi ve spor fakültesi öğrencileridir. Bu sonuçlarda turizm fakültesi, tıp fakültesi ve sağlık fakültesi öğrencilerinin gıda ve sağlık konusundaki farkındalıkları etkili olmuş olabilir.

Araştırmada ekonomik faktörlerin, öğrencilerin yiyecek içecek seçimi algısını etkilediği ve bu algıda harçlığını çalışarak, burs ve kredi ile karşılayan öğrencilerin, harçlığını aile desteği ile karşılayan öğrencilere kıyasla daha etkili olduğu ortaya çıkmıştır. Alkol kullanımı ise kültürel faktörler ve yiyeceğe ilişkin faktörler açısından öğrencilerin yiyecek içecek seçimi algısında farklılığa neden olmaktadır. Alkol kullanmayan öğrenciler yiyeceklerin özelliklerini ve kültürel faktörleri alkol kullanan öğrencilere kıyasla daha fazla dikkate almaktadırlar. Öğrenciler arasında sigara kullanımı ise yiyecek seçiminde herhangi bir algı farklılığına neden olmamaktadır. Araştırmada öğrenciler arasında öğün atlama alışkanlığının da yaygın olduğu ve bu durumun yiyecek içecek seçimi algısı üzerinde etkili olduğu sonucuna ulaşılmıştır. Oysa Chung et al. (2012) mineral içeren besinlerin zihinsel performansı ve konsantrasyonu arttırdığını rapor etmektedirler. $\mathrm{Bu}$ sorunun ortaya çıkmasında ekonomik faktörler ve kültürel faktörler etkili olmaktadır. Bulgular, öğün atlama alışkanlığı olan öğrencilerin öğün atlamayan öğrencilere kıyasla ekonomik faktörlerden ve kültürel faktörlerden daha fazla etkilendiğini ortaya koymaktadır. Bu sonuçlardan hareketle, öğün atlama alışkanlığı yüksek olan öğrencilere yönelik burs gibi ekonomik karakterli desteklerin yanında, kültürel nitelikli zaman yönetimi ve bireysel sorumluluklar gibi konulrda bilinçlendirici eğitimlerin verilmesi önerilebilir.

Araştırma sonuçlarından hareketle, ileride özellikle hedef kitle belirleme, müşteri memnuniyeti ve yeni pazarlama anlayışları geliştirme çalışmalarında bu sonuçların dikkate alınması yararlı olacaktır. Gelecekteki öğrencilerin yiyecek içecek seçimi algısını belirlemeye yönelik çalışmaların cinsiyet, anne eğitim düzeyi ve fakülte farklılığı değişkenlerine odaklanması alan yazına daha fazla katkı sağlayabilecektir.

\section{Kaynakça}

Abraham, S. E., Karns, L. A., Shaw, K., \& Mena, M. A. (2001). Managerial competencies and the managerial performance appraisal process. Journal of Management Development, 20 (9/10), 842-852. https://doi.org/10.1108/02621710110410842

Arıkan, R. (2004). Araştırma Teknikleri ve Rapor Hazırlama, Asil Yayın.

Arslan, P., Karaağaoğlu, N., Duyar, İ. \& Güleç, E. (1994). Yükseköğrenim gençlerinin beslenme alışkanlıklarının puanlandırma yöntemi ile değerlendirilmesi. Beslenme ve Diyet Dergisi, 22 (2), 195-208.

Aydın, İ., Çelik, Y. \& Uğurluoğlu, Ö. (2011). Sağlık Personeli Çalışma Yaşam Kalitesi Ölçeği: Geliştirilmesi, Geçerliliği ve Güvenilirliği. Hacettepe Üniversitesi Toplum ve Sosyal Hizmet Dergisi, 22 (2), 79-100.

Başoğlu, S., Besler, T., Ciğerim, N., Ersoy, G., Karaağaoğlu, N., Pekcan, G., Rakıcıŏlu, N., Sağlam, F., Yurttagül, M. \& Yücecan, S. (1992). Ailelerin Sosyoekonomik ve Gelir Düzeylerine Bağıntılı Olarak Besin Harcama Payları. Beslenme ve Diyet Dergisi, 21, 83100.

Battaglia, M. (2020). Epigenomic landscapes and their relationship to variation, fitness, and evolution. Neuroscience and Biobehavioral Reviews, 109, 90-91. https://doi.org/10.1016/j.neubiorev.2020.01.002 
Bozhüyük, A., Özcan, S., Kurdak, H., Akpınar, E., Saatçı, E. \& Bozdemir, N. (2012). Sağlıklı Yaşam Biçimi ve Aile Hekimliği. Turkish Journal of Family Medicine and Primary Care, $6(1), 13-21$.

Bruening, M., Eisenberg, M., MacLehose, R., Nanney, M. S., Story, M. \& Neumark-Sztainer, D. (2012). Relationship between Adolescents' and Their Friends' Eating Behaviors: Breakfast, Fruit, Vegetable, Whole-Grain, and Dairy Intake. Journal of the Academy of nutrition and dietetics, 112(10), 1608-1613. https://doi.org/10.1016/j.jand.2012.07.008

Bulduk, S. (2013). Glda Teknolojisi, Detay Yayınc1l1k.

Busch, A. M., Blaschek, A., Borggräfe, I., Heinen, F., Straube, A. \& Kries, R. V. (2010). Associations of Diet and Lifestyle With Headache in High-School Students: Results From a Cross-Sectional Study. Headache, 50, 1104-1114.

Büyükpamukçu, M., Oğuz, S. \& İlhan, M. N. (2003). Endüstride Beslenme. Türk Tabipler Birliği Mesleki Sağllk ve Güvenlik Dergisi, 4(15), 40-45.

Chung, Y. C., Park, C. H., Kwon, H. K., Park, Y. M., Kim, Y. S., Doo, J. K., Shin, D. H., Jung, E.S., Oh, M. R. \& Chae, S. W. (2012). Improved cognitive performance following supplementation with a mixed-grain diet in high school students: A randomized controlled trial. Nutrition, 28, 165-172.

Cömert, M. \& Özata, E. (2016). Tüketicilerin Yöresel Restoranları Tercih Etme Nedenleri ve Karadeniz Mutfağı Örneği. Uluslararası Sosyal Araştırmalar Dergisi, 9(42), 1963-1973.

Çalıştır, B., Dereli, F., Eksen, M. \& Aktaş, S. (2005). Muğla Üniversitesi Öğrencilerinin Beslenme Konusunda Bilgi Düzeylerinin Belirlenmesi. Uluslararası İnsan Bilimleri Dergisi, 2(2),18.

Durmaz, H., Sağun, E. \& Tarakçı, Z. (2002). Yüksekokul Öğrencilerinin İçme Sütü Tüketim Alışkanlıkları, YYÜ Vet. Fak. Dergisi,13(1-2), 69-73.

Ermiş, E., Doğan, E., Erilli, N. A. \& Satıc1, A. (2015). Üniversite Öğrencilerinin Beslenme Alışkanlıklarının İncelenmesi: Ondokuz Mayıs Üniversitesi Örneği. Spor ve Performans Araştırmaları Dergisi, 6(1), 30-40. https://doi.org/10.17155/spd.67561

Ersin, M. \& Beyhan, Y. (2001). Toplu Beslenme Sistemlerinde Hijyen Sanitasyonu Sağlama Önerileri. Türk Tabipler Birliği Mesleki Sağllk ve Güvenlik Dergisi, 2(8), 19-26.

Ertürk, M. (2018). Müşterilerin Yiyecek İçecek İşletmeleri Tercihlerinde Etkili Olan Kriterler, Türk Turizm Araştırmaları Dergisi, 2 (1), 85-107. https://doi.org/10.26677/tutad.2018.26

Gama, A. P., Adhikari, K. \& Hoisington, D. A. (2018). Factors influencing food choices of Malawian consumers: A food choice questionnaire approach. Journal of Sensory Studies, 33:e12442, 1-9. https://doi.org/10.1111/joss.12442

Girgin, G. K. \& Karakaş, B. (2017). Türklerin Gıda Tercihlerinde Etkili Olan Motivasyonların Belirlenmesi. Balıkesir Üniversitesi Sosyal Bilimler Enstitüsü Dergisi, 20(38), 425-448. https://doi.org/10.31795/baunsobed.645129

González-Gil, E. M., Martínez-Olivan, B., Widhalm, K., Lambrinou, C. P., Henauw S., Gottrand, F., Kafatos, A., Beghin, L., Molnar, D., Kersting, M., Leclercq, C., Sjöström, M., Fosner, M., González-Gross, M., Breidenassel, C., Castillo, M. J., Dallongeville, J., Rodríguez, G. \& Moreno, L. A. (2019). Healthy eating determinants and dietary patterns in European adolescents: the HELENA study. Child and Adolescent Obesity, 2(1), 18-39. https://doi.org/10.1080/2574254X.2019.1615361 
Gül, K. (2013). Geçmişten Günümüze Mutfak Kültürüne Tarihsel Bir Yaklaşım ve Mutfakta Yeni Eğilimler. Works of the International Scientific-Practical Conference "Development of Science, Education and Culture of Independent Kazakhstan in Conditions of Global Challenges of Modernity”, M. Auezov'un 70. Yıldönümü Anısına, South Kazakhstan State University, Çimkent, Kazakistan, 25-26 Ekim 2013.

Gürsoy, R., Aktaş, Ö. \& Dane, SS. (2001). Beslenme ve Besinsel Ergojenikler I: Karbonhidrat, Yağ ve Proteinler. Atatürk Üniversitesi BESYO Beden Eğitimi ve Spor Bilimleri Dergisi, 1(2), 19-27.

Heşeminia, T., Çalışkan, D. \& Işık, A. (2002). Ankara'da Yüksek Öğretim Öğrenci Yurtlarında Kalan Öğrencilerin Beslenme Sorunları. Ibni Sina Tip Dergisi, 7, 155-167.

Işkın, M. \& Sarışık, M. (2017). Öğrencilerin Besin Tüketim Alışkanlıkları Üzerine Bir Araştırma. Türk Turizm Araştırmaları Dergisi, 1 (1), 33-42. https://doi.org/10.26677/tutad.2017.2

James, D. C. S. (2004). Factors Influencing Food Choices, Dietary Intake, and Nutrition-Related Attitudes among African Americans: Application of a Culturally Sensitive Model. Ethnicity \& Health, 9(4), 349-367.

Kalaycı, Ş. (2006). SPSS Uygulamalı Çok Değişkenli İstatistik Teknikleri, Asil Yayın Dağıtım Ltd.

Keith, J. F., Stastny, S., Brunt, A. \& Agnew, W. (2018). Barriers and Strategies for Healthy Food Choices among American Indian Tribal College Students: A Qualitative Analysis. Journal of the Academy of Nutrition and Dietetics, 118(6), 1017-1026. https://doi.org/10.1016/j.jand.2017.08.003

Korkmaz, N. H. (2010). Uludağ Üniversitesi Öğrencilerinin Spor Yapma ve Beslenme Alışkanlıklarının İncelenmesi. Eğitim Fakültesi Dergisi, 23 (2), 399-413.

Korkmaz, S. (2005). Fast Food (Hızlı Yemek) Pazarında Rekabetçi Stratejilerin Etkinliği: Üniversite Gençliğinin Tercihlerinin Analizi, Ticaret ve Turizm Eğitim Fakültesi Dergisi, 2, 22-39.

Mazıcığlu, M. M. \& Öztürk, A. (2003). Üniversite 3. ve 4. sınıf öğrencilerinde beslenme alışkanlıkları ve bunu Etkileyen faktörler. Erciyes Tıp Dergisi, 25(4), 172-178.

Neumark-Sztainer, D., Story, M., Peery, C. \& Casey, M. A. (1999). Factors influencing food choices of adolescents: Finding from focus-group discussions with adolescents. Journal of the American Dietetic Association, 99(8), 929-937.

Onurlubaşı, E., Doğan, H. G. \& Demirkıran, S. (2015). Üniversite Öğrencilerinin Beslenme Alışkanlıkları. Gaziosmanpaşa Üniversitesi Ziraat Fakültesi Dergisi, 32 (3), 61-69. https://doi.org/10.13002/jafag861

Orak, S., Akgün, S. \& Orhan, H. (2006). Süleyman Demirel Üniversitesi öğrencilerinin beslenme alışkanlıklarının araştırılması. SDÜ Tıp Fakültesi Dergisi, 13(2), 5-11.

Oygard, L. \& Klepp, K-I. (1996). Influences of Social Groups on Eating Patterns: A Study Among Young Adults. Journal of Behavioral Medicine, 19(1), 1-15.

Öncü, A., Çatı, K. ve Özbay, G. (2007). Hızlı Yiyecek İşletmelerinin Tercihinde Etkili Olan Faktörler, Dokuz Eylül Üniversitesi Sosyal Bilimler Enstitüsü Dergisi, 9(1), 317-336.

Özdemir, B. (2010). Dışarıda Yemek Yeme Olgusu: Kuramsal Bir Model Önerisi, Anatolia: Turizm Araştırmaları Dergisi, 21 (2), 218-232. 
Saygın, M., Öngel, K., Çalışkan, S., Yaşlı, M. A., Has, M., Gonca, T. \& Kurt, Y. (2011). Süleyman Demirel Üniversitesi öğrencilerinin beslenme alışkanlıkları. S.D. Ü. Tip Fak. Dergisi, 18(2), 43-47.

Silventoinen, K. \& Konttinen, H. (2020). Obesity and eating behavior from the perspective of twin and genetic research. Neuroscience and Biobehavioral Reviews, 109, 150-165. https://doi.org/10.1016/j.neubiorev.2019.12.012

Swanson, M., Schoenberg, N. E., Davis, R., Wright, S., \& Dollarhide, K. (2013). Perceptions of healthy eating and influences on the food choices of Appalachian youth. Journal of Nutrition Education and Behavior, 45(2), 147-153. https://doi.org/10.1016/j.jneb.2011.07.006

Şahin, F. \& Filiz, S. (1999). Okulöncesi Dönemde Beslenme Kavramının Gelişimi Üzerine Ailenin Etkisi. M. ̈. Atatürk Ĕgitim Fakültesi Eğitim Bilimleri Dergisi, 11, 321-334.

Tanır, F., Şaşmaz, T., Beyhan, Y. ve Bilici, S. (2001). Doğankent Beldesinde Bir Tekstil Fabrikasında Çalışanların Beslenme Durumu. Türk Tabipler Birliği Mesleki Sağllk ve Güvenlik Dergisi, 2 (7), 22-25.

Vançelik, S., Önal, S. G., Güraksın, A. \& Beyhun, E. (2007). Üniversite öğrencilerinin beslenme bilgi ve alışkanlıkları ile ilişkili faktörler. TSK Коrиyиси Hekimlik Bülteni, 6(4), 242-248.

Vanleeuwen, D. M. \& Mandabach, K. H. (2002). A note on the reliability of ranked items. Sociological Methods Research, 31(1), 87-105.

Vilaro, M. J., Zhou, W., Colby, S. E., Byrd-Bredbenner, C., Riggsbee, K., Olfert, M. D., Barnett, T. E. \& Mathews, A. E. (2017). Development and Preliminary Testing of the Food Choice Priorities Survey (FCPS): Assessing the Importance of Multiple Factors on College Students' Food Choices. Evaluation \& the Health Professions, 40(4), 425-449. https://doi.org/10.1177/0163278717735872

Voytyuk, M. \& Hruschka, D. (2017). Cognitive Differences Accounting for Cross-cultural Variation in Perceptions of Healthy Eating. Journal of Cognition and Culture, 17, 116128. https://doi.org/10.1163/15685373-12342194

Yazıcıŏlu, Y. \& Erdoğan, S. (2004). SPSS Uygulamalı Bilimsel Araştırma Yöntemleri, Detay Yayıncilik.

Yıldırım, İ., Yıldırım, Y., Tortop, Y. \& Poyraz, A. (2011). Afyon Kocatepe Üniversitesi Beden Eğitimi ve Spor Yüksekokulu öğrencilerinin beslenme alışkanlıkları ve bunları etkileyen faktörler. Uluslararası İnsan Bilimleri Dergisi, 8(1), 1375-1391.

Yılmaz, E. \& Özkan, S. (2007). Üniversite Öğrencilerinin Beslenme Alışkanlıklarının İncelenmesi. Firat Sağllk Hizmetleri Dergisi, 2(6), 87-104.

Zonneveld, K. L. M., Neidert, P. L., Dozier, C. L., Gureghian, D. L. \& Bayles, M. W. (2019). Assessing factors that influence young children's food preferences and choices. Journal of Applied Behavior Analysis, 52(1), 240-257. https://doi.org/10.1002/jaba.521

Zunft, H. J. F., Friebe, D., Seppelt, B., de Graaf, C., Margetts, B., Schmitt, A. \& Gibney, M. J. (1997). Perceived benefits of healty eating among a nationally-representative sample of adults in the European Union. European Journal of Clinical Nutrition, 2, 41-46. 